\title{
Evaluation and Comparison of Vitamin Profiles of Selected Traditional Rice and Yams Grown in Sri Lanka
}

\author{
W.M.A.A. Kulasinghe, S. Wimalasiri ${ }^{1}$, G. Samarasinghe ${ }^{2}$, R. Silva ${ }^{3}$ and T. Madhujith ${ }^{1 *}$ \\ Postgraduate Institute of Agriculture \\ University of Peradeniya \\ Sri Lanka
}

\begin{abstract}
The current study was designed to evaluate and compare the vitamin composition of selected traditional and improved rice varieties and four Dioscorea spp. commonly grown and consumed in Sri Lanka. Samples were collected from different locations representing all agro-climatic zones of Sri Lanka. The rice samples were cleaned, air-dried, husked, while the yam samples were peeled, freeze-dried, disintegrated and pooled to attain composite samples. These samples were analyzed for vitamins $A, D, E, K 1, B 1$ and B2 using HPLC method. All the samples analyzed were rich in vitamins B1 and B2. Vitamin B2 content in yams were higher than the vitamin B2 content of rice varieties studied. The studied rice varieties contained fat-soluble vitamins $E$ and $K$ only. Vitamin $E$ was found only in traditional rice verities, Kaluheenati, Madathavalu and Suduheenati. Kaluheenati contained all the vitamins and the highest vitamins $E(6.34 \pm 0.01 \mathrm{mg} / 100 \mathrm{~g}), B 1(1.58 \pm 0.06 \mathrm{mg} / 100 \mathrm{~g})$ and B2 $(2.11 \pm 0.03 \mathrm{mg} / \mathrm{lO0g})$ contents. Yams contained fat-soluble vitamins A and Konly. Vitamin A was found only in D. pentaphylla (Katuala). Only D. alata (both Rajala $(0.74 \pm 0.00 \mu \mathrm{g} / 100 \mathrm{~g}$ ) and Angili ala $(0.68 \pm 0.01 \mu \mathrm{g} / 100 \mathrm{~g})$ contained vitamin $K$. Vitamin $K$ content of rice varieties was higher than that of yams studied. The highest vitamin $K$ content was found in Pokkali $(7.55 \pm 0.02 \mu \mathrm{g} / 100 \mathrm{~g})$ and Madathavalu $(1.83 \pm 0.06 \mu \mathrm{g} / \mathrm{l00 \textrm {g }})$ contained the lowest vitamin $\mathrm{K}$ content. The lowest vitamin $K$ content found in rice varieties was higher than the highest vitamin $K$ content available in yams. Traditional and improved rice varieties studied are richer in vitamin $K$ compared to yams.
\end{abstract}

Keywords: HPLC, Sri Lanka, traditional rice, vitamin profiles, yams

\section{INTRODUCTION}

Rice and yams play a vital role as staple foods in number of countries in the world (Elbehri et al., 2013). According to Sarwar et al., (2013) cereals grown in large extents across the world provide more calories than any other type of crops. Therefore, they are considered as staple food crops in many countries including in Sri Lanka. In their natural form or as in whole grain, they are a rich source of vitamins, minerals, carbohydrates, lipids and protein.

Rice (Oryza sativa) is the most significant cereal grown in Sri Lanka. It has been the staple food and the backbone of agricultural sector of Sri Lanka since antiquity. The long history of

\footnotetext{
1 Department of Food Science and Technology, Faculty of Agriculture, University of Peradeniya, Sri Lanka

2 Plant Genetic Resources Center, Peradeniya, Sri Lanka

3 Department of Applied Nutrition, Faculty of Livestock, Fisheries and Nutrition, Wayamba University of Sri Lanka

* Corresponding author: madhujith@yahoo.com
} 
rice cultivation, the wide range of eco-edaphic conditions and various farming systems present in the country have resulted in a wide varietal diversity of rice. Over 3000 rice varieties have been reported in Sri Lanka (Helvetas, 2001).

Yams are the edible tubers of numerous species of the genus Dioscorea and are vital staple food of many tropical countries. Yam is composed mainly of starch, some proteins, lipids, vitamins and minerals (Polycarp et al., 2012). Dioscorea spp. is a popular minor element in Sri Lankan home gardens having the potential of generating large quantities of edible food material with minimal inputs. Dioscorea species are grown in many home gardens, especially in the wet and intermediate zones of Sri Lanka (Sangakkara and Frossard, 2014).

Vitamins are vital for the wellbeing of human and animals to sustain the life. Human body essentially requires small quantities of vitamins for optimal functioning. Insufficient intake of vitamins may lead to many health problems such as blindness, poor reproductive health, risk of anemia, slow growth and may even lead to other health problems such as development of certain cancers, diabetes, obesity and cardio vascular diseases (FAO and WHO, 2001). This is more prominent among children and elderly. Therefore, getting a balanced diet is essential to ensure the human health and nutrition (Hassan, 2012). This study was designed to evaluate and compare the vitamin A, D, E, K1, B1 and B2 contents in selected traditional rice and yams varieties of Sri Lanka.

\section{METHODOLOGY}

\section{Materials}

This study used the following HPLC grade standards and chemicals (Sigma Aldrich, USA) in analysis: vitamins A (retinol acetate), D (ergocalciferol), E ( $\alpha$-tocopherol) and K1 (phylloquinone), vitamins B1 (thiamine) and B2 (riboflavin), Methanol, acetonitrile, ascorbic acid, ethyl alcohol, Potassium hydroxide, sodium chloride, glacial acetic acid, hexane sulphonic acid sodium salt, potassium dihydrogen phosphate and triethylamine, orthophosphoric acid.

Seeds of six traditional red pericarp rice varieties, one traditional white pericarp rice variety, two improved white pericarp rice varieties and one improved red pericarp rice variety were collected for the analysis of vitamins. All the samples collected were harvested during Maha season of year 2015. Further, samples of four yam varieties were collected (Table 1).

\section{Preparation of samples}

A total of $500 \mathrm{~g}$ of healthy, undamaged edible parts (rice kernels and yams) of each sample were collected in polythene bags and transported to the laboratory immediately in temperature controlled containers. Air dried rice samples were husked and disintegrated. Yam samples were peeled, freeze dried (Labconco Lyph Lock 6, USA) and disintegrated. Collected samples were compared with germplasm samples provided by Plant Genetic Resource Center, Gannoruwa, Sri Lanka for authentication. After disintegration, equal amounts of samples received from each agro-climatic zone were pooled and homogenized to obtain the composite sample. The composite samples of ground rice samples were stored in suitable containers and stored under refrigerated at $5{ }^{\circ} \mathrm{C}$. Yam samples were stored under frozen at $-20{ }^{\circ} \mathrm{C}$. The morphological details of yams and rice varieties are given in the Figure 1 and 2, respectively. 
Table 1. Paddy and yam samples collected from different locations

\begin{tabular}{|c|c|c|c|c|c|c|c|}
\hline Crop & Varieties & $\begin{array}{c}\text { Pericarp } \\
\text { Color }\end{array}$ & $\mathbf{W L}$ & WM & IL & IM & DL \\
\hline \multirow[t]{10}{*}{ Rice } & Suwandel & White & $\checkmark$ & $\checkmark$ & $\checkmark$ & $\checkmark$ & $\checkmark$ \\
\hline & Kaluheenati & Red & $\checkmark$ & $\checkmark$ & $\checkmark$ & $\checkmark$ & $\checkmark$ \\
\hline & Kurulutuda & Red & $\boldsymbol{x}$ & $\checkmark$ & $\checkmark$ & $V$ & $\checkmark$ \\
\hline & Madathavalu & Red & $V$ & $\checkmark$ & $\checkmark$ & $V$ & $\checkmark$ \\
\hline & Pachchaperumal & Red & 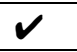 & $V$ & $\checkmark$ & $V$ & $\checkmark$ \\
\hline & Pokkali & Red & $V$ & $V$ & $\checkmark$ & $V$ & $\checkmark$ \\
\hline & SuduHeenati & Red & $V$ & $\checkmark$ & $\checkmark$ & $V$ & $\checkmark$ \\
\hline & $\mathrm{Bg} 360$ & White & $\boldsymbol{x}$ & $\boldsymbol{x}$ & $\checkmark$ & $\boldsymbol{x}$ & $\checkmark$ \\
\hline & $\operatorname{Bg} 352$ & White & $\boldsymbol{x}$ & $\boldsymbol{x}$ & $\checkmark$ & $\boldsymbol{x}$ & $\checkmark$ \\
\hline & AT 362 & Red & $\boldsymbol{x}$ & $\boldsymbol{x}$ & $\boldsymbol{x}$ & $\boldsymbol{x}$ & $\checkmark$ \\
\hline \multirow{4}{*}{ Local yams } & Katuala & & $\checkmark$ & $\checkmark$ & $\boldsymbol{V}$ & $\checkmark$ & $\checkmark$ \\
\hline & Agiliala & & $\checkmark$ & $\checkmark$ & $\checkmark$ & $V$ & $\checkmark$ \\
\hline & Rajala & & $V$ & $\checkmark$ & $\checkmark$ & $\checkmark$ & $\checkmark$ \\
\hline & kukulala & & $v$ & $V$ & $\checkmark$ & $V$ & $\checkmark$ \\
\hline
\end{tabular}

Samples, $\boldsymbol{V}$ : collected $\boldsymbol{*}$ : not collected

WL- Wet Low country, WM- Wet Mid country, IL- Intermediate Low country, IMIntermediate Mid country and DL- Dry Low country.

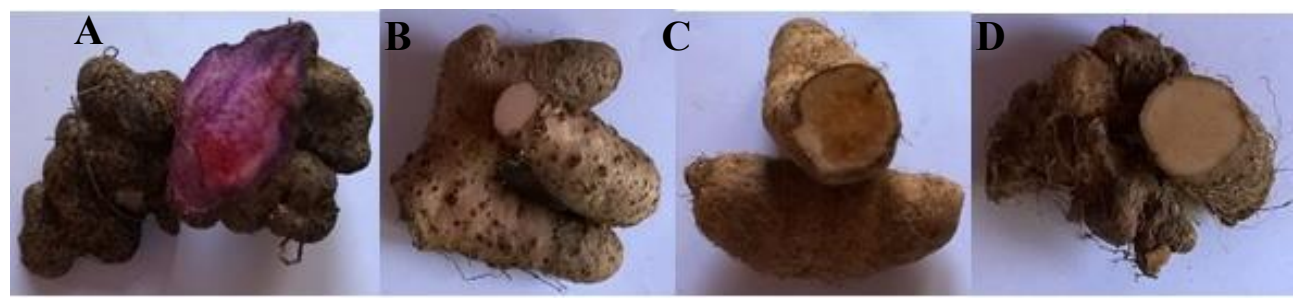

Figure 1. A- Rajala (Dioscorea alata), B-Agiliala (Dioscorea alata), C- Kukulala (Dioscorea esculenta), D- Katuala (Dioscorea pentaphylla)

\section{Quantification of vitamins}

Samples were analyzed for thaimine and riboflavin content by using HPLC method used by Aslam et al. (2008) and vitamin A, D, E and $\mathrm{K}_{1}$ content by using HPLC method described by Aslam et al. (2012). All samples were analyzed in triplicate and if the coefficient of variance was over $15 \%$ the test/s were repeated. 


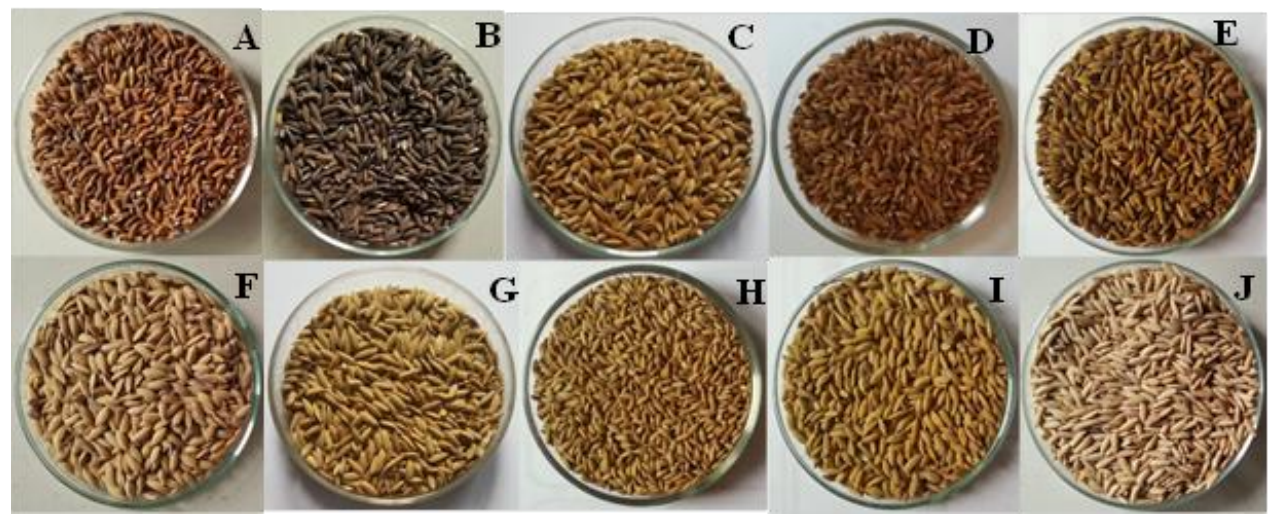

Figure 2. A-Suwandel, B- Kaluheenati, C-Kuruluthuda, D-Madathavalu, EPachchaperumal, F-Pokkali, G-Suduheenati, H-BG 360, I-BG 352 and J-AT 362 varieties.

\section{Analysis of vitamins A, D, E and $\mathrm{K}$}

The mobile phase was prepared by mixing methanol, acetonitrile and water at the ratio of 84:14:2 and filtering through 0.45 micron membrane using Millipore filtration unit. This was degassed using helium. A series of standards of vitamins A (retinol acetate), D (ergocalciferol), $\mathrm{E}$ ( $\alpha$-tocopherol) and $\mathrm{K}_{1}$ (phylloquinone) was prepared in separate $10 \mathrm{~mL}$ volumetric flasks. The final volume $(10 \mathrm{ml})$ was made up using methanol.

Five grams of each sample was weighed, transferred into $100 \mathrm{ml}$ conical flask and the contents were mixed with $0.5 \mathrm{~g}$ ascorbic acid and $25 \mathrm{~mL}$ ethyl alcohol and shaken for $5 \mathrm{~min}$. Next, $5 \mathrm{~mL}$ of $12 \mathrm{~N} \mathrm{KOH}$ was added and heated under reflux for $30-40 \mathrm{~min}$ at $80^{\circ} \mathrm{C}$, cooled down over $30 \mathrm{~min}$. Then sample was separately extracted with $50 \mathrm{~mL}, 30 \mathrm{~mL}$ and $20 \mathrm{~mL}$ diethyl ether, respectively. For quick separation, 2-3 drops of sodium chloride were added. Final solution was concentrated to obtain $1 \mathrm{~mL}$ of sample. Resulted $1 \mathrm{~mL}$ of sample was dissolved in $5 \mathrm{~mL}$ HPLC grade methanol. Extracted samples were filtered through $0.45 \mu \mathrm{m}$ syringe filters. HPLC analysis was performed using C18 column $(4.6 \times 250 \mathrm{~mm} 5 \mu \mathrm{m})$ with a linear gradient of methanol, acetonitrile and water (84:14:2) at a constant flow rate of $1 \mathrm{~mL} / \mathrm{min}, 30 \mathrm{~min}$ of run time and injection volume of $20 \mu \mathrm{L}$. A UV detector was engaged for the detection of peaks, using two channels simultaneously at a wavelength of $295 \mathrm{~nm}$, a bandwidth of $4 \mathrm{~nm}$ and another wavelength of $280 \mathrm{~nm}$. All the analyses were performed in triplicates. Vitamins were quantified using regression equation of calibration curve of each standard.

\section{Analysis of vitamins B1 and B2}

The mobile phase was prepared by mixing $50 \mathrm{~mL}$ of acetonitrile and $10 \mathrm{~mL}$ of glacial acetic acid and volume was made up to $1000 \mathrm{~mL}$ using double distilled water. The final mixture was filtered through 0.45 micron membrane using Millipore filtration unit. Buffer was prepared by dissolving $1.08 \mathrm{~g}$ of hexane sulphonic acid sodium salt and $1.36 \mathrm{~g}$ of potassium dihydrogen phosphate in $940 \mathrm{~mL}$ of double distilled water and $5 \mathrm{~mL}$ of triethylamine was added to the solution. The final $\mathrm{pH}$ was adjusted to 3.0 with orthophosphoric acid. Buffer and methanol were mixed at a ratio of $96: 4$ and filtered through $0.45 \mu \mathrm{m}$ membrane filter and degassed using helium. Standards of vitamins B1 (thiamine) and B2 (riboflavin) were prepared in separate 10 
$\mathrm{mL}$ volumetric flasks. The final volume $(10 \mathrm{ml})$ was made up using double distilled filtered water.

Ten grams of each sample was weighed and transferred into conical flasks and $25 \mathrm{ml}$ of extraction solution was added, kept on a shaking water bath at $70{ }^{\circ} \mathrm{C}$ for $40 \mathrm{~min}$. Next, the sample was cooled down, filtered and finally the volume was made up to $50 \mathrm{~mL}$ with extraction solution. Extracted samples were filtered through $0.45 \mu \mathrm{m}$ syringe filters. HPLC analysis was performed using a C18 column $(4.6 \times 250 \mathrm{~mm} 5 \mathrm{~m})$ with a linear gradient of Buffer: methanol (96:4) at a constant flow rate of $1 \mathrm{ml} / \mathrm{min}, 25$ minutes of run time and $60 \mu \mathrm{L}$ of injection volume. A UV detector was engaged in the detection of peaks, using 3 channels simultaneously at a wavelength of $210 \mathrm{~nm}, 270 \mathrm{~nm}$ and $280 \mathrm{~nm}$ with a bandwidth of $5 \mathrm{~nm}$. All the analyses were performed with 3 replicates. The vitamin yield was quantified using regression equation of calibration curve of each standard.

\section{Determination of recovery and precision of estimation}

The accuracy of the method was tested by a recovery study. Pre-analyzed samples were spiked with $50 \%, 100 \%$ and $150 \%$ excess of the standard vitamins and re-analyzed following the same method. The experiment was repeated 3 times, average recovered vitamins content was quantified using regression equation and the percent recovery was calculated accordingly. The precision of the used method was calculated by determining inter and intra-day variations in the three replicates of vitamins at two concentration levels (200-400 ng per spot) and the Percent Standard Relative Deviation (RSD) was calculated.

\section{Statistical analysis}

One-way analysis of variance was carried out on the experimental results. The significance of differences between means was compared by Tukey's Multiple Comparisons Procedure. All calculations were performed using SAS 9 statistical software.

\section{RESULTS AND DISCUSSION}

\section{Vitamin composition of traditional rice varieties}

Vitamin content of traditional rice varieties is shown in Table 2. Cereals are a good source of vitamins from the vitamin B group. In industrial countries, they provide nearly 50-60\% of the daily requirement of $\mathrm{B}$ vitamins. The most predominant fat-soluble vitamin is tocopherol, which exists in concentrations above $20 \mathrm{mg} / \mathrm{kg}$. Vitamins are concentrated in the outer layers of the grains, especially in the aleurone layer as well as in the germ. Therefore, milling of rice grains into white will eliminate most of the vitamins. Thus, the consumption of whole grain will be of nutritional benefit for the consumer (Gobbetti and Gänzle, 2013). Gobbetti and Gänzle (2013) reported that same traditional rice varieties tested in this study were rich in Vitamins B1 and B2 as well as Vitamin E out of fat-soluble vitamins. In addition to vitamin $\mathrm{E}$, vitamin $\mathrm{K}$ was found in the samples tested. Vitamins A and D were not detected during this analysis in the same way reported by Longvah et al., (2017). Only Kaluheenati, Madathavalu and Suduheenati rice varieties contained vitamin E while the highest vitamin E content found in Kaluheenati. 
All the traditional rice varieties possessed vitamin $\mathrm{K}$ while only Bg 360 contained vitamin $\mathrm{K}$ out of improved rice varieties tested. Remarkably, the highest vitamin K content was found in Pokkali while the lowest vitamin K level of $1.83 \pm 0.06 \mu \mathrm{g} / 100 \mathrm{~g}$ was found in Madathavalu. The highest vitamin B1 (thiamine) content was found in Kaluheenati and the second highest vitamin B1 content was found in Suduheenati. Vitamin B1 contents of Kuruluthuda, Pachchaperumal, Pokkali, Bg 352 and At 362 were not significantly different $(\mathrm{p}<0.05)$. Meanwhile, they contained the lowest levels of thiamine compared to other rice varieties analyzed. The vitamin B2 (riboflavin) content of all tested rice varieties was higher than the thiamine levels. The riboflavin content ranged from $0.39 \pm 0.00 \mathrm{mg} / 100 \mathrm{~g}$ to $2.11 \pm 0.03 \mathrm{mg} / 100$ g. Kaluheenati possessed the highest riboflavin content compared to other rice samples analyzed. Pachchaperumal and Pokkali contained the exactly similar amounts of vitamin B2 (Table 2).

Table 2. Vitamin content of selected rice varieties*

\begin{tabular}{lcccc}
\hline \multicolumn{1}{c}{ Rice variety } & $\begin{array}{c}\text { Vitamin E } \\
(\mathbf{m g} / \mathbf{1 0 0} \mathbf{g})\end{array}$ & $\begin{array}{c}\text { Vitamin K } \\
(\boldsymbol{\mu g} / \mathbf{1 0 0} \mathbf{g})\end{array}$ & $\begin{array}{c}\text { Vitamin B1 } \\
(\mathbf{m g} / \mathbf{1 0 0} \mathbf{g})\end{array}$ & $\begin{array}{c}\text { Vitamin B2 } \\
(\mathbf{m g} / \mathbf{1 0 0} \mathbf{g})\end{array}$ \\
\hline Suwandel & $\mathrm{N} / \mathrm{D}$ & $4.29 \pm 0.01^{\mathrm{d}}$ & $0.73 \pm 0.00^{\mathrm{d}}$ & $1.26 \pm 0.00^{\mathrm{c}}$ \\
Kaluheenati & $6.34 \pm 0.01^{\mathrm{a}}$ & $3.64 \pm 0.04^{\mathrm{e}}$ & $1.58 \pm 0.06^{\mathrm{a}}$ & $2.11 \pm 0.03^{\mathrm{a}}$ \\
Kuruluthuda & $\mathrm{N} / \mathrm{D}$ & $5.03 \pm 0.01^{\mathrm{c}}$ & $0.44 \pm 0.00^{\mathrm{e}}$ & $0.17 \pm 0.00^{\mathrm{g}}$ \\
Madathavalu & $2.07 \pm 0.00^{\mathrm{b}}$ & $1.83 \pm 0.06^{\mathrm{g}}$ & $0.70 \pm 0.01^{\mathrm{d}}$ & $0.56 \pm 0.01^{\mathrm{b}}$ \\
Pachchaperumal & $\mathrm{N} / \mathrm{D}$ & $6.93 \pm 0.01^{\mathrm{b}}$ & $0.43 \pm 0.00^{\mathrm{e}}$ & $0.94 \pm 0.00^{\mathrm{d}}$ \\
Pokkali & $\mathrm{N} / \mathrm{D}$ & $7.55 \pm 0.02^{\mathrm{a}}$ & $0.38 \pm 0.01^{\mathrm{e}}$ & $0.94 \pm 0.00^{\mathrm{d}}$ \\
Suduheenati & $1.67 \pm 0.00^{\mathrm{c}}$ & $4.27 \pm 0.01^{\mathrm{d}}$ & $1.04 \pm 0.01^{\mathrm{b}}$ & $0.39 \pm 0.00^{\mathrm{f}}$ \\
Bg 360 & $\mathrm{N} / \mathrm{D}$ & $2.08 \pm 0.00^{\mathrm{f}}$ & $0.93 \pm 0.00^{\mathrm{c}}$ & $1.62 \pm 0.01^{\mathrm{b}}$ \\
Bg 352 & $\mathrm{N} / \mathrm{D}$ & $\mathrm{N} / \mathrm{D}$ & $0.38 \pm 0.00^{\mathrm{e}}$ & $0.86 \pm 0.02^{\mathrm{e}}$ \\
At 362 & $\mathrm{N} / \mathrm{D}$ & N/D & $0.36 \pm 0.02^{\mathrm{e}}$ & $0.80 \pm 0.01^{\mathrm{e}}$ \\
$\mathrm{p}$ Value & 0.000 & 0.000 & 0.000 & 0.000 \\
\hline
\end{tabular}

*Data represent the mean of three replicates fresh weight basis. Values followed by the different superscript in each column are significantly different $(\mathrm{P}<0.05)$

Considering vitamin profiles of all the rice varieties analyzed, traditional rice varieties found to be rich in vitamins compared to improved rice varieties tested. According to International Union for Conservation of Nature (2016) traditional varieties were contain higher concentrations of vitamins and richer in fiber while possess a lower glycemic index compared to improved rice varieties.

\section{Vitamin composition of selected traditional yams}

Table 3 shows the vitamins found in traditional yams. Only vitamins A, K, B1 and B2 were found in yams analyzed. Vitamins D and E were not detected in yams tested. It was observed that the water soluble vitamin content was higher than that of the fat soluble content in yams tested. Vitamin A was found only in Katuala (D. pentaphylla) at $26.25 \pm 1.09 \mathrm{mg} / 100 \mathrm{~g}$ level and it was the only fat-soluble vitamin found in Katuala (D. pentaphylla). Vitamin K or Phylloquinon was only found in Angiliala and Rajala which comes under the same species $D$. alata. Rajala (D. alata) possessed $0.74 \pm 0.00 \mathrm{mg} / 100 \mathrm{~g}$ and Angili ala (D. alata) contained $0.68 \pm 0.01 \mathrm{mg} / 100 \mathrm{~g}$ which was significantly different from Rajala (D. alata). 
The highest thiamine or vitamin B1 content was found in Katuala (D. pentaphylla) while the second highest thiamine level was detected in Rajala (D. alata). Kukulala (D. esculenta) consisted with $0.66 \pm 0.02 \mathrm{mg} / 100 \mathrm{~g}$ of thiamine while the lowest vitamin $\mathrm{B}_{1}$ content of $0.34 \pm 0.02 \mathrm{mg} / 100 \mathrm{~g}$ was found in Angili ala (D. alata).

Table 2. Vitamin content of selected traditional yams*

\begin{tabular}{lcccc}
\hline Yam variety & $\begin{array}{c}\text { Vitamin A } \\
(\boldsymbol{\mu g} / \mathbf{1 0 0} \mathbf{g})\end{array}$ & $\begin{array}{c}\text { Vitamin K1 } \\
(\boldsymbol{\mu g} / \mathbf{1 0 0} \mathbf{g})\end{array}$ & $\begin{array}{c}\text { Vitamin B1 } \\
(\mathbf{m g} / \mathbf{1 0 0} \mathbf{~})\end{array}$ & $\begin{array}{c}\text { Vitamin B2 } \\
(\mathbf{m g} / \mathbf{1 0 0} \mathbf{g})\end{array}$ \\
\hline Katuala & $26.25 \pm 1.09$ & $\mathrm{~N} / \mathrm{D}$ & $1.28 \pm 0.02^{\mathrm{a}}$ & $2.93 \pm 0.02^{\mathrm{a}}$ \\
Angiliala & $\mathrm{N} / \mathrm{D}$ & $0.68 \pm 0.01^{\mathrm{b}}$ & $0.34 \pm 0.02^{\mathrm{d}}$ & $2.61 \pm 0.03^{\mathrm{b}}$ \\
Rajala & $\mathrm{N} / \mathrm{D}$ & $0.74 \pm 0.00^{\mathrm{a}}$ & $1.04 \pm 0.00^{\mathrm{b}}$ & $0.76 \pm 0.00^{\mathrm{d}}$ \\
Kukulala & $\mathrm{N} / \mathrm{D}$ & $\mathrm{N} / \mathrm{D}$ & $0.66 \pm 0.02^{\mathrm{c}}$ & $2.49 \pm 0.01^{\mathrm{c}}$ \\
$p$ Value & & 0.00 & 0.00 & 0.00 \\
\hline
\end{tabular}

*Data represent the mean of three replicates fresh weight basis. Values followed by the different superscript in each column are significantly different $(\mathrm{P}<0.05)$

Vitamin B2 or riboflavin levels detected in selected yams were higher than the thiamine levels detected. As same as the thiamine content Katuala (D. pentaphylla) contained the highest riboflavin content. Although Angili ala (D. alata) contained the lowest amount of thiamine it contained second highest riboflavin content of $2.61 \pm 0.03 \mathrm{mg} / 100 \mathrm{~g}$. Rajala (D. alata) consisted with the lowest vitamin $\mathrm{B}_{2}$ content of $0.76 \pm 0.00 \mathrm{mg} / 100 \mathrm{~g}$ while Kukulala (D. esculenta) contained $2.49 \pm 0.01 \mathrm{mg} / 100 \mathrm{~g}$ of riboflavin level.

Of all the yams tested, Katuala (D. pentaphylla) was rich in vitamins compared to other yams. Poornima \& Ravishankar (2009) reported that Dioscorea tubers contained approximately 1.67 $\mathrm{mg} / 100 \mathrm{~g}$ of ascorbic acid, $0.70 \mathrm{mg} / 100 \mathrm{~g}$ of thiamin and $0.43 \mathrm{mg} / 100 \mathrm{~g}$ of riboflavin. Okwu \& Ndu (2006) have shown that vitamin C content of Dioscorea yams varied from 0.44 $\mathrm{mg} / 100 \mathrm{~g}$ to $1.93 \mathrm{mg} / 100 \mathrm{~g}$ while riboflavin level ranged between $0.001 \mathrm{mg} / 100 \mathrm{~g}$ and $0.009 \mathrm{mg} / 100 \mathrm{~g}$ and thiamine level varies from $0.007 \mathrm{mg} / 100 \mathrm{~g}$ to $0.01 \mathrm{mg} / 100 \mathrm{~g}$. USDA National Nutrient Database (2008) reports that approximate ascorbic acid, thiamine and riboflavin contents of Dioscorea yams as $17.1 \mathrm{mg} / 100 \mathrm{~g}, 0.11 \mathrm{mg} / 100 \mathrm{~g}$ and $0.03 \mathrm{mg} / 100 \mathrm{~g}$ respectively. According to Longvah et al., (2017) potatoes (Solanum tuberosum) which is commonly consumed tuber crop worldwide contains $0.06 \pm 0.004 \mathrm{mg} / 100 \mathrm{~g}$ of vitamin B1, $0.01 \pm 0.001 \mathrm{mg} / 100 \mathrm{~g}$ of vitamin B2, $1.26 \pm 0.31 \mathrm{mg} / 100 \mathrm{~g}$ of vitamin $\mathrm{D}, 0.01 \pm 0.01 \mathrm{mg} / 100 \mathrm{~g}$ vitamin E and $3.00 \pm 0.34 \mathrm{mg} / 100 \mathrm{~g}$ vitamin K. It shows Dioscorea spp studies were richer in water soluble vitamins compared to potatoes. There are considerable variations among the values reported by different authors in different studies. These differences can be due to the different environmental, soil and climatic conditions which analyzed yams grown. Composition of deposits of a plant is highly affected by the environment. The samples obtained in this study represent the whole Sri Lanka and they were obtained from different agro-climatic zones. Even the studies mentioned above also have conducted in different parts of the world. Therefore, this environmental variation is reflected by the different compositional valued obtained by different analysts. 


\section{CONCLUSIONS}

All traditional rice and yam samples analyzed were rich in vitamin B1 and B2. Vitamin B2 content in yams studied was higher than the vitamin B2 content of traditional rice varieties studied. However, rice varieties contained only vitamin $\mathrm{E}$ and $\mathrm{K}$ out of the fat-soluble vitamins. Vitamin E was found only in Kaluheenati, Madathavalu and Suduheenati, which were red pericarp rice varieties. Vitamin $\mathrm{K}$ was available in all rice varieties analyzed except in $\mathrm{Bg} 352$ and At 362, which were two improved rice varieties. Kaluheenati contained all these vitamins while holding the highest vitamin E, B1 and B2 amounts.

Yams analyzed were contained only vitamin A and $\mathrm{K}$ out of the fat-soluble vitamins. Vitamin A was only found in D.pentaphylla (Katuala). Only D. alata (both rajala and Angili ala) contained vitamin $\mathrm{K}$. However, vitamin $\mathrm{K}$ contents of rice varieties were higher than the vitamin K contents of yams studied. The highest vitamin K content was found in Pokkali and Madathavalu contained the lowest vitamin $\mathrm{K}$ content, which was already higher than the vitamin $\mathrm{K}$ content available in yams. Therefore, rice varieties studied were richer in vitamin $\mathrm{K}$ compared to yams studied.

\section{ACKNOWLEDGEMENT}

The authors express their gratitude to Department of Institute of Post-Harvest Technology, Anuradapura, Sri Lanka. Special thanks also go to the United Nations Environment Program and Food and Agriculture Organization of United Nations for funding and Plant Genetic Resource Center, Department of Agriculture, Sri Lanka for supplying the samples.

\section{REFERENCES}

Aslam, J., Khan, S.H., Khan, S.A., (2012). Variation in fat soluble vitamins (A, D, E, K) in in vitro and ex vitro germinated chickpea (Cicer arietinum L.) seedlings, as revealed by high performance liquid chromatography. J Saudi Chem Soc, 16(2), 125-129.

Aslam, J., Mohajir, M .S., Khan, S .A., Khan, A.Q., (2008). HPLC analysis of water-soluble vitamins (B1, B2, B3, B5, B6) in in vitro and ex vitro germinated chickpea (Cicer arietinum L.). Afr J Biotechnol, 7(14), 2310-2314.

Elbehri, A, Kaminski, J, Koroma, S, Iafrate, M, Benali, M., (2013), West Africa food systems: An overview of trends and indicators of demand, supply, and competitiveness of staple food value chains, In: Rebuilding West Africa's Food Potential, A. Elbehri (ed.), FAO/IFAD, pp.1125.

FAO and WHO, (2001). Human Vitamin and Mineral Requirements.Food and Agriculture Organization and World Health Organization, Bangkok, Thailand. pp.303.

Gobbetti, M. and Gänzle, M., (2013). Handbook on sourdough biotechnology, German Research Center for Food Chemistry ,Lise-Meitner-Strasse 34 , 85354 Freising, Germany.2, pp11-39.

Hassan, B.A.R., (2012) Vitamins (Importance and Toxicity). Pharmaceutica Analitica Acta 3:e125. doi:10.4172/2153-2435.1000e125. 
Helvetas Sri Lanka, (2001). Sustainable Farming System through Traditional Plant Genetic Resources and Indigenous Knowledge Based Practices, Helvetas, Sri Lanka. pp. 1-137.

International Union for Conservation of Nature, (2016). Rice farming : back to some traditional practices in the Kapiriggama Village Tank Cascade System Rice farming: back to some traditional practices in the Kapiriggama Small Tank Cascade System, pp.1-18. IUCN, Sri Lanka.

Longvah, T., Ananthan, R., Bhaskarachary, K., Venkaiah, K., (2017). Indian Food Composition Tables. International Institute of Nutrition, Indian Council of Medical Research, Telangana State, India, (6), 61-91.

Okwu, D.E., Ndu, C.U., (2006). Evaluation of the phytonutrients, mineral and vitamin contents of some varieties of yam (Dioscorea sp.). Int J Mol Med and Adv Sci, 2(2), 199-203.

Polycarp, D., Afoakwa, E. O., Budu, A. S., Otoo, E., (2012). Characterization of chemical composition and anti-nutritional factors in seven species within the Ghanaian yam ( Dioscorea ) germplasm. Int Food Res J, 19(3), 985-992.

Poornima, G.N. Ravishankar, R.V., (2009). Evaluation of phytonutrients and vitamin contents in a wild yam, Dioscorea belophylla (Prain) Haines. Afr J Biotechnol, 8(6), 971-973.

Sangakkara, R., Frossard, E., (2014). Home gardens and Dioscorea species - A case study from the climatic zones of Sri Lanka. J Agr Rural Dev Trop Subtrop, 115(1), 55-65.

Sarwar, M.H., Sarwar, M. F., Sarwar, M.Q., Niaz, A.M., Safia, M., (2013). The importance of cereals ( Poaceae: Gramineae ) nutrition in human health: A review. J Cereals OilSeeds, 4(June), 32-35.

USDA National Nutrient Database, (2008). Yams nutrition facts and health benefits. [Online]. [Accessed on 5th August 2017].Available at: <https://www.nutrition-andyou.com/yams.html.> 